\title{
Performance and Carcass Yield of Broilers Supplemented with Plant Extract During the Finisher Phase
}

ISSN 1516-635X Oct - Dec 2014 / v.16 / n.4 / 443-448

http://dx.doi.org/10.1590/1516-635x1604443-448

Technical Note

\section{-Author(s)}

Carlos TCF

Barbosa LCGS'

Polycarpo GV

Afonso $E R^{\prime}$

Utimi NBPI

Bortolato C"

Araújo CSS

Araújo LF

Department of Animal Nutrition and Production, FMVZ/USP, Pirassununga, campus, Brazil teresa_cristina_c@hotmail. com

" Evonik Degussa do Brasil Ltda. carlos. bortolato@evonik.com

\section{ABSTRACT}

In this study, 600 one-day-old male Cobb 500 broilers were distributed according a completely randomized experimental design into the different dietary treatments. Broilers were fed the following dietary treatments: positive control diet (PC), containing 54 ppm zinc bacitracin; negative control diet (NC), with no inclusion of performance enhancers and $3 \%$ reduction in metabolizable energy, crude protein, and amino acid levels; PC up to 33 days and then NC, with the dietary addition of 75, 150, or 225 ppm plant extracts, until day 42 days of age. Broiler performance and carcass yield were evaluated. Data were analyzed using the Statistical Analysis System package (SAS Institute Inc., 2008), and submitted to polynomial regression analysis using the GLM procedure at 5\% significance level. There was no influence of treatments on feed intake or weight gain, but feed conversion ratio of the broiler fed the plant extract was significantly higher $(p<0.05)$ compared with those fed the antibiotic. There was no significant effect ( $p>0.05)$ of the applied treatments on carcass yield. We concluded that the replacement of performance-enhancing additives by plant extracts, at the evaluated inclusion levels, does not promote positive performance results.

\section{INTRODUCTION}

Brazil is the third global producer of chicken meat, with more than 13 million tons, closely following China, which is the second largest producer, with 13.2 million tons, and the United States, with 16.8 million tons. The domestic market accounts for $69.8 \%$ of sales of Brazilian chicken meat, whereas $30.2 \%$ are exported to more than 150 countries, mainly to the Middle East (UBABEF, 2012).

The European Union is our fourth largest importer. In 2006, this important consumer market banned the inclusion of antimicrobial products at subtherapeutic doses as performance-enhancing additives in the diet of livestock due to the possible presence of residues in animal products and the cross-resistance of human pathogens. The use of antibiotics and chemotherapeutic drugs are allowed only for therapeutic purposes (Palermo, 2006).

The withdrawal of antibiotic as performance enhancers from poultry feeds causes a chain reaction: intestinal health is negatively affected, leading to worse performance and, consequently, to worse productivity. In addition, mortality may increase and together, these factors make production more expensive and reduce profitability, which result in higher meat prices.

Therefore, new strategies need to be developed to prevent those negative effects. There are currently several new feed additives alternative to antibiotics in the market for broiler feeds, including probiotics, prebiotics, plant extracts, organic acids, etc. The additives 
promote better gastrointestinal tract function by changing the $\mathrm{pH}$ or by manipulating the gut microflora. Plant extracts and essential oils have been shown to be a possible alternative to replace antibiotics in animal feeds (Botsoglou et al., 2002; Bruno, 2008; Bampidis et al., 2005). Considering the wide variety of plants, which contain several different compounds, the biggest challenge for their utilization of plant extracts as alternative to antimicrobial products is the identification and evaluation of their effects on animals (Kamel, 2000).And one of the essential requirement for the utilization of such products for animal feeding is the absence of toxicity.

Therefore, the present experiment aimed at evaluating the performance and carcass yield of broilers fed diets supplemented with performance-enhancing antibiotic until 33 days old, which was then replaced by plant extracts until the end of the rearing period.
The following dietary treatments were applied: positive control diet (PC), containing 54 ppm zinc bacitracin; negative control diet (NC), with no inclusion of performance enhancers and 3\% reduction in metabolizable energy, crude protein, and amino acid levels; PC up to 33 days and then NC with the dietary addition of 75,150 , or 225 ppm plant extracts until day 42 days of age, as shown in Table 1.

The experimental diets were formulated to supply the nutritional requirements recommended by Rostagno et al. (2011) for the starter (1-21 days), grower (22-33 days), and finisher (34-42 days) phases. In order to obtain precise feed formulation, gross energy, crude protein, and amino acid levels of corn and soybean meal were analyzed before diets were manufactured at the feed mill of the University of São Paulo, Pirassununga campus.

\section{MATERIAL AND METHODS}

The experiment was carried out at the Center of Poultry Research of the School of Veterinary Medicine and Animal Science of Universidade de São Paulo, Pirassununga campus, Brazil. Six hundred oneday-old Cobb 500 male broilers were distributed according to a completely randomized experimental design into five treatments with 10 replicates of 12 birds each housed in 50 pens. Each pen was considered as one experimental unit. Birds were reared until 42 days of age.

The mixture of plant extracts included in the diet consisted of a combination of the aromatic substances carvacrol $(5 \%)$, capsaicin $(2 \%)$, and cinnamaldehyde (3\%), which are naturally found in oregano, chili, and cinnamon, respectively. These substances were chosen for their possible performance-enhancing effect. The plant extracts were microencapsulated and in powder. The mixture was added to the premix before feed mixture to obtain better distribution of the product in the feed.
Table 1 - Ingredients and nutritional composition of the experimental diets, according to feeding phase.

\begin{tabular}{|c|c|c|c|c|c|c|}
\hline \multirow[t]{2}{*}{ Ingredients, kg } & \multicolumn{2}{|c|}{ Starter } & \multicolumn{2}{|c|}{ Grower } & \multicolumn{2}{|c|}{ Finisher } \\
\hline & $P C^{*}$ & $N C * \star$ & $P C$ & $\mathrm{NC}$ & $\mathrm{PC}$ & NC \\
\hline Corn & 58.56 & 61.99 & 62.59 & 64.95 & 67.18 & 69.15 \\
\hline Soybean meal & 35.53 & 33.46 & 30.58 & 28.80 & 26.57 & 25.01 \\
\hline Soybean oil & 1.820 & 0.000 & 3.300 & 1.650 & 3.030 & 1.580 \\
\hline Dicalcium phosphate & 1.760 & 1.770 & 1.330 & 1.340 & 1.110 & 1.110 \\
\hline Calcitic limestone & 0.810 & 0.820 & 0.810 & 0.820 & 0.740 & 0.740 \\
\hline Salt & 0.450 & 0.450 & 0.420 & 0.430 & 0.400 & 0.400 \\
\hline DL-methionine & 0.340 & 0.320 & 0.290 & 0.270 & 0.260 & 0.250 \\
\hline L-lysine & 0.330 & 0.330 & 0.300 & 0.310 & 0.320 & 0.330 \\
\hline L-threonine & 0.120 & 0.130 & 0.090 & 0.090 & 0.100 & 0.090 \\
\hline Mineral supplement ${ }^{1}$ & 0.100 & 0.100 & 0.100 & 0.100 & 0.100 & 0.100 \\
\hline Vitamin supplement ${ }^{2}$ & 0.100 & 0.100 & 0.100 & 0.100 & 0.100 & 0.100 \\
\hline Anticoccidial agent ${ }^{3}$ & 0.050 & 0.000 & 0.050 & 0.000 & 0.050 & 0.000 \\
\hline Antibiotic $^{4}$ & 0.036 & 0.000 & 0.036 & 0.000 & 0.036 & 0.000 \\
\hline Inert material & 0.000 & 0.530 & 0.000 & 1.140 & 0.000 & 1.140 \\
\hline Total & 100.00 & 100.00 & 100.00 & 100.00 & 100.00 & 100.00 \\
\hline \multicolumn{7}{|c|}{ Calculated nutritional composition } \\
\hline Metabolizable energy $(\mathrm{kcal} / \mathrm{kg})$ & 3005 & 2915 & 3150 & 3050 & 3200 & 3100 \\
\hline Crude protein (\%) & 21.80 & 21.15 & 19.80 & 19.21 & 18.40 & 17.85 \\
\hline Digestible lysine (\%) & 1.270 & 1.230 & 1.130 & 1.100 & 1.060 & 1.030 \\
\hline Digestible methionine (\%) & 0.640 & 0.610 & 0.580 & 0.550 & 0.538 & 0.522 \\
\hline Digestible met + cys, \% & 0.920 & 0.890 & 0.830 & 0.800 & 0.774 & 0.751 \\
\hline Digestible threonine (\%) & 0.830 & 0.810 & 0.740 & 0.710 & 0.689 & 0.668 \\
\hline Digestible valine (\%) & 0.880 & 0.850 & 0.770 & 0.750 & 0.738 & 0.715 \\
\hline Calcium (\%) & 0.880 & 0.880 & 0.760 & 0.760 & 0.663 & 0.663 \\
\hline Available phosphorus (\%) & 0.440 & 0.440 & 0.350 & 0.350 & 0.309 & 0.309 \\
\hline Sodium (\%) & 0.220 & 0.220 & 0.210 & 0.210 & 0.195 & 0.195 \\
\hline
\end{tabular}

${ }^{*} \mathrm{PC}$, positive control. **NC, negative control. 'Guaranteed levels of the mineral supplement added at $1 \mathrm{~kg} /$ ton of feed: copper (min) 8000 mg/kg; iron (min) $50 \mathrm{~g} / \mathrm{kg}$; iodine (min) $1200 \mathrm{mg} / \mathrm{kg}$; manganese (min) $70 \mathrm{~g} / \mathrm{kg}$; selenium (min) 200 $\mathrm{mg} / \mathrm{kg}$; zinc (min) $50 \mathrm{~g} / \mathrm{kg} .{ }^{2}$ Guaranteed levels of the vitamin supplement added at 1 kg/ton of feed: folic acid (min) 1000 mg/kg; pantothenic acid (min) $15 \mathrm{~g} / \mathrm{kg}$; niacin (min) $40 \mathrm{~g} / \mathrm{kg}$; Vitamin A (min) 8000000 IU/kg; Vitamin B1 (min) 2400 mg/kg; Vitamin B12 (min) 14000 mcg/kg; Vitamin B2 (min) 6000 mg/kg; Vitamin B6 (min) 4000 mg/kg; Vitamin D3 (min) 2400000 IU/kg; Vitamin E (min) 12000 IU/kg; Vitamin K3 (min) 2000 mg/kg. ${ }^{3}$ AnticoccidiaL agent: Coxistac (12\%). ${ }^{4}$ Antibiotic product: Zinc bacitracin (15\%). 
Birds were housed in a conventional masonry broiler house, covered with fibrocement tiles, and the sides were equipped with a wire mesh and with interior and exterior blue canvas curtains. The concrete floor was covered with reused wood-shavings litter to increase health challenge. The house was divided in 140 pens $\left(1 \mathrm{~m}^{2}\right)$. Chick feeders were used until day 5, and then replaced by tube feeders. Pens were equipped with nipple drinkers. Water and mash feed were supplied ad libitum.

During the first days, a gas brooder was used to maintain optimal environment temperature. The lighting program was applied according to the genetic line manual. The house was equipped with a negative ventilation system with evaporative cooling pads and a control panel that adjusted house temperature and humidity according to bird needs and environmental conditions (Table 2).

Table 2 - Average experimental house temperature and humidity recorded during the experimental period (1-41 days of age).

\begin{tabular}{ccccc}
\hline & \multicolumn{2}{c}{ Average temperature, ${ }^{\circ} \mathrm{C}$} & \multicolumn{2}{c}{ Average humidity, \% } \\
\cline { 2 - 5 } & Maximum & Minimum & Maximum & Minimum \\
\hline $1-42$ days & 29.65 & 22.14 & 79.69 & 50.30 \\
\hline
\end{tabular}

Birds were weighed on days 1, 33, and 42. Feed remaining in the feeders on the last day of each feeding phase were also weighed. These data were used to calculate weight gain, feed intake, and feed conversion ratio. Feed intake was calculated as the difference between feed supply and feed residues, which were weighed at the beginning and end of the experimental period, divided by the number of birds in each pen. Feed conversion ratio was calculated by dividing feed intake by weight gain per period. Mortality was daily checked and recorded, and birds presenting abnormal development were culled daily and their numbers were recorded. These records were used to correct performance data for mortality.

At the end of the experimental period, at 42 days of age, birds were sacrificed at the teaching processing plant of the University of São Paulo, Pirassununga campus. Two birds with the average weight of their experimental unit, totaling 100 birds, were selected, individually weighed, and sacrificed according to the requirements of the Brazilian humane slaughter legislation. Birds were previously fasted for six hours to allow emptying their gastrointestinal tract.

After stunning, bleeding, scalding, feather-plucking, manual evisceration, and removal of the head and neck, carcasses were chilled and then maintained in cold storage for two hours before cutup. Breast and legs (thigh+drumstick) from individual carcasses were weighed. Cold eviscerated carcasses without the head and neck were weighed to determine carcass yield relative to live weight. Parts yield were calculated relative to the weight of the cold eviscerated carcasses without the head, neck, and feet.

Data were analyzed using the Statistical Analysis System package (SAS Institute Inc., 2008) after testing the assumptions of residue normality by the test of Shapiro-Wilk (PROC UNIVARIATE). Live performance and carcass yield data were submitted to polynomial regression analysis using the GLM procedure at 5\% significance levels, classifying treatment effects as linear, quadratic, or cubic, as a function of orthogonal contrasts.

\section{RESULTS AND DISCUSSION}

Live performance results of broilers fed a diet containing or not an antibiotic up to 33 days of age and then diets with no antibiotics and supplemented with plant extracts during the finisher phase are presented in Table 3.

During the period of 32 to 42 days of age, feed intake and weight gain were not significantly different among treatments $(p<0.05)$. However, during the same period, broilers fed plant extracts presented significantly higher feed conversion ratio compared with those fed the positive-control diet that contained the antibiotic. Therefore, the increasing inclusion of plant extracts in replacement of the antibiotic in the feed did not have a positive effect on broiler performance.

Table 3 - Feed intake (FI), weight gain (WG), and feed conversion ratio (FCR) results of broilers fed diets containing an antibiotic or not up to 33 days of age, and then diets with no antibiotic and supplemented with plant extracts during the finisher phase.

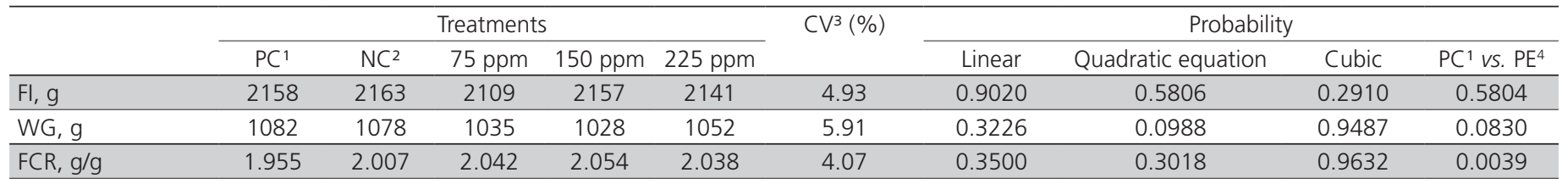

${ }^{1} \mathrm{PC}$, positive control. ${ }^{2} \mathrm{NC}$, negative control. ${ }^{3} \mathrm{CV}$, coefficient of variation. ${ }^{4} \mathrm{PE}$, plant extracts. 
Due to the lack of studies evaluating the utilization of plant extracts only in finisher broiler feeds, and because the efficacy of these extracts strictly depends on their composition and inclusion levels, it is difficult to compared these results with studies that assessed the dietary inclusion of these extracts in broiler diets during the entire rearing period.

Nevertheless, it should me mentioned those studies obtained discrepant results. For instance, Barreto et al. (2008) evaluated the effects of the dietary addition of 1000 ppm oregano extract, 1000 ppm clove extract, 1000 ppm cinnamon extract, 1000 ppm red chili extract, 10 ppm avilamycin, and of a control diet on broiler performance, and did not find any influence of the treatments on feed intake, weight gain, or feed conversion ratio in none of the studied rearing periods. Other authors, such as Hernández et al. (2004), Toledo et al. (2007), Rizzo et al. (2010), and Petrolli et al. (2012), also did not find any effects of the dietary supply of plant extracts to 1- to 42-day-old broilers on any performance parameters. On the other hand, García et al. (2007) fed broilers with formic acid; 200 ppm of oregano, cinnamon, and chili extracts; 500 ppm of sage, thyme, and rosemary extracts; a negativecontrol diet; and a diet with 10 ppm avilamycin and observed lower feed conversion ratio in all treatments compared with the negative-control diet and that with sage, thyme, and rosemary extract supplementation.

According to Hernández et al. (2004), broiler fed plant extracts present better performance when compared with those fed diets with no additives and similar performance relative to broilers fed antibiotic performance enhancers. However, as most studies are carried out in low health challenge environments, performance results are similar between broilers fed diets supplemented or not with additives (Fukayama et al., 2005; Toledo et al., 2007).

According to Lee et al. (2003), the absence of performance effects with the dietary inclusion of plant extracts may be due to the composition of the basal diet and/or to the environmental conditions experienced by the birds during the experiment. Highly digestible feedstuffs limit the proliferation of bacteria in the intestinal tract because no substrate is left for bacterial growth, and therefore, the antimicrobial potential of plant extracts may not be apparent. This is also observed when broilers are reared under low immune challenge conditions and strict health control.

Another possible reason for these results is the applied antibiotic performance enhancer, zinc bacitracin, immediately exerts its effects, whereas plant extracts require longer times to control the intestinal microbiota.

Carcass yield results of broilers fed a diet containing or not an antibiotic up to 33 days of age and then diets with no antibiotics and supplemented with plant extracts during the finisher phase (33 to 42 days of age) are presented in Table 4.

Carcass, breast, and leg yields were not different ( $p>0.05$ ) when the broilers fed plant extracts between 34 and 42 days were compared with those fed the diet with antibiotic.

These results are different from the findings of Jamroz et al. (2005), who obtained higher breast yield in broilers fed diets supplemented with a mixture of carvacrol, cinnamaldehyde, and capsaicin compared with those fed a control diet. Zhang et al. (2005) compared a diet with the inclusion of $100 \mathrm{ppm}$ of oregano, cinnamon, thyme, and chili extracts in replacement of an antibiotic with a basal diet and observed that broilers fed the plant extracts presented lower leg yield relative to those fed the basal diet; however, carcass, breast, and wing yields were similar between treatments.

We expected that the dietary inclusion of plant extracts would improve carcass yield as a result of better dietary amino acid digestion, which would favor muscle deposition.

\section{CONCLUSIONS}

Under the conditions of the present experiment and considering the included plant extract levels, we concluded that the inclusion of a mixture of

Table 4 - Carcass yield results of broilers fed a diet containing or not an antibiotic up to 33 days of age and then diets with no antibiotics and supplemented with plant extracts from 34 to 42 days of age.

\begin{tabular}{|c|c|c|c|c|c|c|c|c|c|c|}
\hline & \multicolumn{5}{|c|}{ Treatments } & \multirow[t]{2}{*}{$\mathrm{CV}^{3}(\%)$} & \multicolumn{4}{|c|}{ Probability } \\
\hline & $\mathrm{PC}^{1}$ & $\mathrm{NC}^{2}$ & 75 ppm & 150 ppm & $225 \mathrm{ppm}$ & & Linear & Quadratic & Cubic & $P C^{1}$ vs. $P E^{4}$ \\
\hline Carcass, \% & 72.44 & 72.26 & 72.66 & 72.85 & 72.52 & 1.67 & 0.5864 & 0.3567 & 0.8653 & 0.6228 \\
\hline Breast, \% & 29.71 & 30.12 & 30.56 & 31.02 & 30.63 & 4.82 & 0.3497 & 0.3856 & 0.6769 & 0.0708 \\
\hline Leg, \% & 30.83 & 30.66 & 30.33 & 30.24 & 30.57 & 2.10 & 0.7106 & 0.1315 & 0.8573 & 0.0750 \\
\hline
\end{tabular}

${ }^{1} \mathrm{PC}$, positive control. ${ }^{2} \mathrm{NC}$, negative control. ${ }^{3} \mathrm{CV}$, coefficient of variation. ${ }^{4} \mathrm{PE}$, plant extracts. 
oregano, chili, and cinnamon extracts in broiler diets in replacement of an antibiotic performance enhancer did not promote any performance or carcass yield benefits when compared with the diet containing the antibiotic.

\section{ACKNOWLEDGEMENTS}

The authors than FAPESP for funding the experiment and the companies Evonik and Pancosma for supplying the plant extract product.

\section{REFERENCES}

Bampidis VA, Christodoulou V, Florou-Paneri P, Christaki E, Chatzopoulou PS, Tsiligianni T, Spais A.B. Effect of dietary dried oregano on growth performance, carcase characteristics and serum cholesterol of female early maturing turkeys. Britsh Poultry Science 2005;46(5):595-601.

Barreto MSR, Menten J FM, Racanicci AMC, Pereira PWZ, Rizzo PV. Plant extracts used as growth promoters in broilers. Brazilian Journal of Poultry Science 2008;10(2):109-115.

Bruno DG. Efeito de um fito composto no desempenho de leitões submetidos ao desafio experimental com Salmonella typhimurium [dissertação].Dissertação (Mestrado). Pirassununga (SP): Universidade de São Paulo; 2008. 137p

Botsoglou NA, Florou-Paneri P, Christaki E. Effect of dietary oregano essential oil on performance of chickens and on iron-induced lipid oxidation of breast, thigh and abdominal fat tissues. Britsh Poultry Science 2002;43(2):223-230.

Cobb. Cobb 500 Suplemento de crescimento e nutrição para frangos de corte. São Paulo: Cobb-Vantress Brasil; 2008. 8p.

Fukayama EH, Bertechini AG, Geraldo A, Kato RK, Murgas LDS. Extrato de Orégano como Aditivo em Rações para Frangos de Corte. Revista Brasileira de Zootecnia 2005;34(6):2316-2326.

García V, Catalá-gregori P, Hernández F, Megías MD, Madrid J. Effect of formic acid and plant extracts on growth, nutrient digestibility, intestine mucosa morphology, and meat yield of broilers. The Journal of Applied Poultry Research 2007;16(4):555-562.

\section{Performance and Carcass Yield of Broilers Supplemented with Plant Extract During the Finisher Phase}

Hernández F, Madrid J, García V, Orengo J, Megías MD. Influence of two plant extracts on broilers performance, digestibility, and digestive organ size. Poultry Science 2004;83(2):169-174.

Jamroz D, Wiliczkiewicz A, Wertelecki T, Orda J, Skorupinska J. Use of active substances of plant origin in chicken diets based on maize and domestic grains. British Poultry Science 2005;46:485-493.

Kamel C. A novel look at a classic approach of plant extracts. Feed Mix The International Journal on Feed, Nutrition and Technology - Special: Alternatives to antibiotics. Doetinchen 2000;9(6):19-24.

Lee KW, Kappert HJ, Frehner M, Losa R, Beynen AC. Effects of dietary essential oil components on growth performance, digestive enzymes and lipid metabolism in female broiler chickens. British Poultry Science 2003; 44:450-457.

Palermo JN. Uso de medicamentos veterinários: Impactos na moderna avicultura. Anais so Simpósio Brasil Sul de Avicultura; 2006; Chapecó, Santa Catarina. Brasil. p.70-78.

Petrolli TG. Extratos herbais em dietas de frangos de corte [dissertação] Viçosa (MG): Universidade Federal de Viçosa; 2009

Rizzo PV, Menten JFM, Racanicci AMC, Traldi AB, Silva CS, Pereira P W Z. Extratos vegetais em dietas para frangos de corte. Revista Brasileira de Zootecnia 2010;39(4):801-807.

Rostagno HS, Albino LFT, Donzele JL, Gomes PC, Oliveira RF, Lopes DC Ferreira AS, Barreto SLT, Euclides RF. Tabelas brasileiras para aves e suínos: composição de alimentos e exigências nutricionais. $3^{a}$ ed. Viçosa: UFV, DZO; 2011. 252 p.

Statistical Analysis System. SAS user's guide: statistics. Version 9.2. Cary: SAS; 2008.

Toledo GSP, Costa PTC, Silva LP, Pinto D, Ferreira P, Poletto CJ. Desempenho de frangos de corte alimentados com dietas contendo antibiótico e/ ou fitoterápico como promotores, adicionados isoladamente ou associados. Ciência Rural 2007;37(6):1760-1764.

União Brasileira De Avicultura. Relatório Anual 2012 [cited 2012 Out 1]. São Paulo: União Brasileira de Avicultura; 2012. 113 p. Available from: http:// www.abef.com.br/ubabef/exibenoticiaubabef.php?notcodigo=3293.

Zhang KY, Yan F, Keen CA, Waldroup PW. Evaluation of microencapsulated essential oils and organic acids in diets for broiler chickens. International Journal of Poultry Science 2005;4(9):612-619. 
